\title{
Da fantasia à História: folheando páginas revisteiras
}

Ana Luiza M ARTIN $S^{1}$

RESU Mo: Este texto trata do uso da revista como fonte histórica, procurando apontar suas características de documento múltiplo para recuperação da História, insistindo na necessidade preliminar de sua crítica exaustiva, em função do caráter mercantil e/ou ideológico que preside tais publicações. Concomitantemente, levanta dois aspectos que demandam análise apurada: a segmentação que preside o periódico e que define sua linha editorial e as ilustrações que o compõe, sem perder de vista as seções que conformam a publicação. Toma como exemplo revistas paulistanas de 1890 a 1920.

Palavras-chave: revista, ilustração, História de São Paulo.

A reconstrução do passado - desafio tanto maior quanto as inúmeras possibilidades suscitadas por novas técnicas e abordagens vem sendo objeto de tratamentos vários, passíveis de resultarem eles próprios em referenciais históricos fundamentais de períodos eépocas em que foram formulados. A valorização do fato na histoire événementielle de Jules M ichelet (1798-1874), ou aquela dita científica e organizada no quadro do Estado, como a quis Leopold Ranke (1795-1886), seguida da contribuição marxista até chegarmos à diversificação de fontes e abordagens sugeridas pela École des Annales, no século XX, constituem-se em indicadores que, por si sós, revelam a historicidade, valores e até mesmo as conquistas metodológicas que presidiram os respectivos tempos.

Ao longo destas contribuições é extenso o rol de fontes convencionais, tradicionalmente manuseadas pel o historiador e credenciadas como documentos legítimos a respaldar as investigações acadêmico-cien- 
tíficas. N este conjunto, o "impresso revista” não se apresenta de forma inédita como fonte histórica, uma vez que desde o século XIX os periódicos já eram considerados documentos pertinentes para o rastreamento do passado, ainda que com restrições. Todavia, as imensas possibilidades de análise decorrentes da N ova H istória potencializaram o gênero "revista" como fonte, ou melhor, esta modalidade de publicação periódica evidenciou-se como suporte rico e diversificado de documentos, síntese privilegiada de instantâneos reveladores de processos históricos, representação material de práticas de consumo, usos e costumes.

Logo, a atração suscitada pela revista como documento, tornou-a irresistível, conjunto lúdico que numa só publicação reúne texto, imagem, técnica, visões de mundo e imaginários coletivos. Todos os seus componentes, aparentemente corriqueiros - formato, papel, letra, ilustração, tiragem - sugerem indagações que prenunciam a carga de historicidade presente nas, hoje, velhas e amarelecidas publicações. Tem-se ali registro múltiplo, do textual ao iconográfico, do extra texto - reclame ou propaganda - à segmentação, do perfil de seus proprietários àquele dos consumidores.

Texto, imagem, ilustrações, reclames e seções - em princípio, independentes de análise mais profunda - , evocam em seu conjunto, de imediato, o quadro histórico em que se pretende transitar. E criam, igualmente, o risco de leitura amena eligeira, decorrente do mero foIhear dessas publicações de época que acabam por envolver o leitor/historiador no tempo pretérito que busca reconstruir. 0 processo de aliciante sedução é passível de levá-lo a registros precipitados e equivocados decorrentes, sobretudo, das mensagens edulcoradas da publicidade, ou por vezes enviesadas da propaganda. Razão pela qual a fonte requer cuidados, em face dos apel os que transportam e induzem o pesquisador a configurações quase pictóricas do passado.

N esse sentido, a constância do uso de revistas como fonte histórica vem revelando que frases e imagens de periódicos pinçadas aqui e acolá, descosturadas do mergulho em seu tempo - vale dizer, no imaginário construído ao seu tempo - não iluminam suficientemente o passado. A pertinência desse gênero de impresso como testemunho do período só é válida se levarmos em consideração as condições de sua 
produção, de sua negociação, de seu mecenato propiciador, das revoluções técnicas a que se assistia e, em especial, da natureza dos capitais nele envolvidos.

Razão pela qual a abordagem desse texto caminha no sentido de acentuar a importância do gênero revista quando trabalhado empiricamente, à luz da história cultural, procurando evidenciar suas inúmeras possibilidades.

ATENTOS À ARMADILHA DOCUMENTAL

Insista-se que, sobretudo na virada do século XIX para o século $X X$, quando o jornal ismo transformava-se em grande empresa, o caráter mercantil dos periódicos se acentuou, criados quase exclusivamente como "negócio" e fonte de lucros. N esse propósito, veiculavam o que era rentável no momento, procurando "suprir a lacuna" do mercado, atender a expectativas e interesses de grupos, segmentando públicos, conformando-os aos model os em voga; e, na maioria das vezes, a serviço da reprodução do sistema. Em outras palavras, desde então as revistas em geral matizavam a realidade, veiculando imagens conciliadoras de diferenças, atenuando contradições, destilando padrões de comportamento, conformando o público leitor às demandas convenientes à maior circulação e ao consumo daquele impresso. O u seja: expressavam o comprometimento apriorístico com aquilo que o leitor queria ler e "ouvir".

Uma vez desmontado o ideário vendido pelo periódico, revela-se quanto de suas páginas - aparentemente isentas e até graficamente assépticas - destilava toda uma propaganda e/ou proposta passível de envolvimento e cooptação, mascarando e empanando a realidade. As distorções e os disfarces - traços que demandam al erta quando se trabalha com propaganda e publicidade - , disseminam-se no impresso revista, exigindo de seu pesquisador o exercício da crítica permanente do documento, interna e externa, passível de aflorar o verso e reverso de uma mesma história, ou possi bilitar as múltiplas histórias decorrentes do fato, do momento, do período, de um processo histórico. 
A recuperação de libelo indignado na revista literária paulista Í ris, de 1905, é fato esclarecedor dos comprometimentos dessa "indústria" a seu tempo, percebido e combatido pela crítica coeva, que denunciava a submissão do periodismo aos anseios da opinião pública:

O jornalismo que se faz indústria, longe de guiar e esclarecer a opinião, procura inspirar-se nela, sonda precatadamente suas ten dências, afaga seus gestos, anima suas inclinações, corteja seus pendores, acaricia-lhe - quantas vezes! - as aberrações mórbidas repulsivas, (...) num apagamento de critério, numa obliteração de vergonha. Mas (...) não perde o leitor de todo dia, o freguês da mofina, o freguês dos anúncios, o freguês dos editais. No campo da estética, na arena da política, no domínio da moral, semelhante jornalismo não quer ter, não pode ter e não tem opinião própria, opinião redatorial, opinião responsável; esposa a média das opiniões de todo o mundo, pensa como todo o mundo e assim é lido por todo mundo. ${ }^{2}$

No Brasil do entresséculo passado, traços muito peculiares vincaram o periodismo que se profissionalizava e se conscientizava de seu poder, ensaiando a entrada na grande imprensa. Um deles diz respeito à diversidade temática de uma mesma publicação, dotada de inúmeras seções. N os limites deste texto não cabe anali sar pontualmente cada uma delas, até porque é o conjunto da publicação que deve ser considerado na sua instância de fonte documental. Duas peculiaridades, contudo, demandam análise circunstanciada e não devem ser perdidas de vista pelo historiador do impresso periódico: a segmentação que o preside e a ilustração que o completa.

Vamos por partes.

\section{ENTRE TIPOLOGIAS E SEGMENTAÇÕES}

Preliminar e decisivo na utilização da revista sob o aspecto de fonte periódica é definir a segmentação que a norteia, procurando inferir o público para o qual se dirige, identificando interesses, valores e téc- 
nicas de cooptação de mercado. A sugestão - aparentemente elementar no trato de qualquer documento pelo historiador - reveste-se de exigências específicas na esfera desse impresso, entre outras razões, pela dinâmica que o preside, inserido no sistema de produção, circulação e consumo, com vistas à ampla divulgação no mercado. Corresponder às expectativas dos consumidores é pré-requisito do periódico que pretendeatingir eampliar seu público, viabilizando-se como produto mercantil. Se isso é possível hoje - através de uma imprensa claramente segmentada - , no passado não foi assim. Inicialmente, pela tardia formação de público leitor e consumidor no Brasil - entre outras razões - pelo atraso com que a imprensa chegou até nós, pela ordem escravocrata que inibiu o consumo e pelo alto índice de analfabetismo do País. A demora em enfrentar a questão determinou longo período de ensaio e erro, no qual a característica mais difusa do periodismo foi, exatamente, aquela da indefinição de segmentos de consumo.

Logo, Revista de Variedades, Revistas I lustradas e Revistas Literárias - por vezes tão confinadas no dúbio qualificativo de "mundanas" - foram subtítulos indefectíveis que acompanharam as publicações na emergência da grande imprensa, procurando atingir a mais indistinta e alta gama de leitores, quando se fazia concessão de toda ordem para ampliar a vendagem, com vistas a garantir o sucesso econômico do periódico. Assim, nas volúveis chamadas de capa ocorriam mudanças freqüentes, presididas pela "mera intuição" de novo segmento consumidor, ou pela viabilidade de propostas temáticas alternativas submetidas, sobremaneira, aos modismos sugeridos pelos periódicos estrangeiros. Esportivas, literárias e de humor eram apel os recorrentes de capa, os quais nem sempre correspondiam aos seus conteúdos.

O confronto com a imensa quantidade de títulos periódicos indiscriminados no período de 1890 a 1922³ só na cidade de São Paulo - amostragem significativa pela efervescência da "capital do café" permite uma primeira sistematização de temáticas que delineia públicos leitores e permite vislumbrar a emergente segmentação, passo fundamental para o estabelecimento da crítica ao documento revista. As décadas iniciais republicanas, de 1890 a 1900, demandaram o compulsar individual de centenas de exemplares para inferir recorrências e de- 
finir conteúdos; já para os decênios seguintes o quadro anexo revelouse de utilidade, noticiando as tipologias e revelando, inclusive, sua nomenclatura de época. Insista-se que também este quadro deve ser visto com reservas, dados os propósitos, naturezas e mesmo precisão duvidosa com que se realizavam as estatísticas oficiais do período, (ver TABELA 1).

A amostragem revela, de imediato, o surgimento de novas demandas, a exemplo das revistas esportivas, corporativas, infantis e cinematográficas, enquanto o escrutínio das temáticas no quadro da nova ordem republicana permite outras ilações. A recuperação, contudo, de títulos periódicos no alvorecer conjunto da República e do século XX permitiu vislumbrar conteúdos abraçados por aquele periodismo, explicitamente afinados com o projeto republicano e, na seqüência, com a demanda conjuntural do novo Estado e do País. Desse confronto resultaram tipologias de revistas, que indiretamente acenavam com a inicial estratificação de públicos consumidores, delineando também a subseqüente segmentação geográfica, econômica e social que norteou a imprensa no Brasil. Circunstâncias de contexto que demandam sempre ampla consideração quando se trata de trabalhar com a fonte revista.

À guisa de exemplo dos resultados obtidos no escrutínio e análise do periodismo do período em apreço, seguem al guns resultados, eventuais contribuições para o usuário da revista como documento.

\section{ORDENANDO TÍTULOS}

O compulsar de mais de duzentos títulos periódicos da imprensa paulistana das três décadas iniciais do século XX permitiu selecionar temáticas reveladoras dos principais focos de interesse da nova ordem, bem como delinear grupos leitores afinados com o impresso e sua propagação.

Inicial mente, a ênfase dada aos temas caros à República permitiu o lançamento expressivo de revistas educacionais e pedagógicas, que encontraram terreno fértil para proliferar, particularmente no Estado mais escolarizado do País. Nas três décadas subseqüentes, o público al- 
TABELA 1

PRODUÇÃO PERODÍSTICA DO BRASIL: 1912-1930

\begin{tabular}{|c|c|c|c|c|}
\hline NATUREZA & 1912 & 1930 & DIFERENÇA & PORCENTAGEM \\
\hline Noticiosos & 882 & 1.519 & +637 & $+72,2$ \\
\hline Literários & 118 & 297 & +79 & $+151,2$ \\
\hline Religiosos & 84 & 272 & +188 & $+223,8$ \\
\hline Científicos & 58 & 212 & +154 & $+265,5$ \\
\hline Humorísticos & 57 & 99 & +42 & $+73,6$ \\
\hline Comerciais & 23 & 82 & +59 & $+256,5$ \\
\hline Anunciadores & 19 & 72 & +53 & $+278,9$ \\
\hline Almanaks & 14 & 66 & +52 & $+371,4$ \\
\hline Esportivos & 5 & 58 & +53 & $+1.060,0$ \\
\hline Corporativos & & 48 & +48 & \\
\hline Oficiais & 21 & 44 & +23 & $+109,5$ \\
\hline Agronômicos & 23 & 34 & +11 & $+47,8$ \\
\hline Didáticos & 8 & 33 & +25 & $+312,5$ \\
\hline Estatísticos & 11 & 29 & +18 & $+163,6$ \\
\hline Espíritas & 22 & 21 & -1 & $-4,5$ \\
\hline Históricos & 7 & 14 & +7 & $+100,0$ \\
\hline M ilitares & 6 & 11 & +5 & $+83,0$ \\
\hline Industriais & 2 & 11 & +9 & $+450,0$ \\
\hline Infantis & 1 & 11 & +10 & $+1.000,0$ \\
\hline Cinematográficos & & 10 & +10 & \\
\hline M açônicos & 10 & 7 & -3 & $-30,0$ \\
\hline Marítimos & 3 & 6 & +3 & $+100,0$ \\
\hline Filosóficos. & 3 & 3 & & \\
\hline TOTAL & 1.377 & 2.959 & +1.582 & $+114,9$ \\
\hline
\end{tabular}

FONTE: Estatística da Imprensa Periódica no Brasil. Rio de Janeiro: Tipografia do Departamento Nacional de Estatística, 1931. 
fabetizado crescera, a emergente classe média se conformava ávida de ascensão, saber e consumo, enquanto a imprensa periodística, mais experiente e profissionalizada, dispunha de uma rede de apoio ampliada, com serviços de comunicação otimizados. E mais: conquistava-se novo espaço para o homem de letras colocar-se graficamente, voltado para um público efetivamente consumidor do impresso. Ressalte-se, no entanto, naquelas publicações, o propósito uniformizador do discurso, veiculado segundo interesses do poder oficial, instância definidora da sobrevivência e eventual sucesso daquelas iniciativas.

Por outro lado, o aparelhamento institucional laico nascido com a República, em seu propósito de negação da I greja, encontrou no periodismo larga representação, quando sucederam-se revistas científicas einstitucionais, instrumentos que deram força, significado e visibilidade às realizações daquele campo de interesses até então inusitado, legitimando as agremiações institucionais e científicas nascidas com o novo regime.

Em contraposição, disseminaram-se as revistas religiosas, ben eficiadas pela recente liberdade de cultos, opondo-se ferrenhamente à pregação secular então encetada, cumprindo papel decisivo no controle da palavra e das mentes.Valendo-se de significativos recursos materiais, com gráficas próprias, bem aparelhadas e contando com subsídios vários, as revistas de cunho religioso alastraram-se, não raro qualificadas pela colaboração de talentosos articulistas e ilustradores do período. M aior circulação ainda obtinham as revistas de origem católica, com entrada garantida nos lares, vistas como inofensivas e benéficasàsfamílias deformação cristã, queconformavam a imensa maioria do País.

Todavia, no país agrícola, as revistas ditas "agronômicas", vale dizer, revistas agrícolas, constituíram-se em importante fatia do mercado periódico, potencializado pelo incentivo à pequena propriedade, quando do imperioso parcelamento de parte dos latifúndios - muito em favor de imigrantes em ascensão. 0 agricultor de médio porte passou a ser também um leitor, engrossando as fileiras do público consumidor, resultando o gênero agrícola em filão comercial dos mais atraen- 
tes para investimentos, contemplando de anúncios de implementos agrícolas à necessária orientação técnica sobre produtos do campo.

Surpreendente, contudo, o sucesso repentino das revistas esportivas, no País que havia pouco importara os modismos dos jogos britânicos - o football e o lawn tenis - , aquele já disseminando-se pelo povo e este, praticado pela elite. Era necessário divulgar com presteza a novidade dos torneios, os resultados do turfe, as partidas entre os clubes, os matches. Nesse ritmo, rapidamente, esportistas amadores improvisaram-se em editores, percebendo naquele segmento da imprensa um nicho de mercado. M ais consumidores, mais anunciantes e mais lucrativo se tornava o negócio. Com vistas a ampliar esta população leitora, estavam as estratégias de venda - da coleção de fotos de atletas da moda à organização seriada de coleções - o que garantia a circulação do periódico entre faixas etárias diversas, atingindo, principalmente, o público jovem; ou por outra, a população recém - alfabetizada dos primeiros anos da República.

N ão se pode ignorar a imensa quantidade de revistas étnicas, resultado da imigração diversificada que se acentuara a partir dos anos de 1880. A comunidade italiana, mais expressiva, editou números de qualidade, inclusive bilíngües, contando com expressivo público leitor; mas também puseram revistas em circulação os grupos de imigrantes espanhóis, alemães, sírios e mais tarde japoneses, que inclusive dispunham de gráficas próprias, ainda que rudimentares.

Consolidando e ampliando um tradicional segmento leitor, as re vistas femininas imperaram naquele periodismo alvissareiro. Contribuíram para tanto o investimento na alfabetização, a inicial profissionalização da mulher e a ressonância dos movimentos sufragistas e feministas internacionais. Escolarizada, atenta às modas e figurinos de seu tempo, a leitora feminina encontrou nas revistas a alternativa de aquisição do impresso, não apenas como leitora, mas sobretudo como consumidora de produtos de toda ordem, anunciados estrategicamente pela imprensa comprometida com o lucro. M ais que isso, a mulher da jovem República redesenhava sua imagem a partir daquele "espelho da moda", isto é, as sedutoras revistas da época. Assim, fosse pelo viés da produção escrita feminina ou aquele da divulgação dos figurinos 
da moda, ou ainda aquele outro perpetrado pela propaganda, paulatinamente principiavam a desestabilizar-se as fronteiras simbólicas entre os sexos, desfazendo-se papéis ancestral mente construídos na secular sociedade patriarcal brasileira. ${ }^{4}$

Todavia, não só a revista de mercado ganhou espaços e gerou comportamentos. 0 registro de mais de cem periódicos da imprensa operária só na capital e cinqüenta no interior, no período em apreço, é sugestivo da importância das "revistas de esquerda" no quadro da imprensa paulistana. ${ }^{5}$ Segmento de exclusão, carregando o estigma de ameaçadoras à ordem vigente e alvos constantes da censura, aquelas publicações não se limitaram à propagação das idéias libertárias. Coube-Ihes papel importante na efetiva divulgação da leitura e consumo do impresso, numa proporção até mais acentuada que aquela da imprensa burguesa, conformando o público operário ao exercício das letras e às práticas culturais de sua classe, entre elas, o teatro. ${ }^{6}$

Por outro lado, na esteira das então agônicas revistas teatrais vicejaram as revistas cinematográficas, que entravam não só sob influxo da magia de Holywood, mas pelo condão da publicidade via modelo yankee, que imprimia em cores as estampas dos artistas e dos "maraviIhosos produtos importados", ambos veiculados conjuntamente naquelas alienantes páginas revisteiras.

Entretanto, um segmento explodiu com mai or força e veio para ficar: aquele das revistas infantis. "Isto eu li no Tico-Tico", foi a afirmação veemente de Rui Barbosa, que valeu por ampla e definitiva publicidade do gênero. A conquista desse público, naquele momento, colocou-se como elo conclusivo da cooptação de mercados para o impresso periódico em ampla propagação.

Nesta seqüência, élícito admitir que em meados dos anos de 1920, particularmente, a imprensa paulistana já tinha clara a segmentação daquela sociedade complexa, marcada pela coexistência de diversas etnias, várias corporações, múltiplos segmentos leitores e mercados consumidores alternativos. O s impressos periódicos agora vinham à luz direcionados para públicos específicos, libertando-se do aposto Variedades. Nesse novo contexto nasceram entre São Paulo e Rio de Janeiro: A O rdem, revista de cultura do Centro D. Vital (1921); A Cena M uda, 
revista cinematográfica (1921); Klaxon, mensário de arte moderna (1922); Vamos Ler (1936), voltada para a potencializada população escolar, entre outras.

Toda esta rica gama de temáticas, públicos e conteúdos merece estudos circunstanciados no quadro da revista como fonte histórica. Razão pela qual também é temerário limitar-se tão-só à análise do discurso destas publicações; ou pinçar de seus textos frases e/ou parágrafos avulsos que corroborem determinadas afirmações, desalinhadas de seus contextos. Assim como é imprescindível o cotejo com suas partes, bem como imperiosas sua contextualização e decodificação, seja na instância de sua emergência como naquela da desconstrução do discurso e na análise das ilustrações que a compõem.

Insista-se que este último cuidado no tocante à imagem, inerente às revistas ilustradas, vem sendo objeto de tratamentos vários decorrentes, em especial, da sociologia da arte e dos estudos de arte gráfica. Nesse sentido, a ilustração - seja aquela da composição decorativa da página, ou aquela da propaganda e ainda aquela outra da caricatura constitui representação com forte carga documental, merecendo breve incursão.

O TRAÇO EM LUGAR DO TEXTO

Tem sido registrada amiúde a concorrência entre texto e imagem nas revistas ilustradas da virada do século XIX para o século XX. Isto é bastante perceptível na imprensa periodística brasileira deste período, presidida por uma coincidência temporal favorável aos experimentos gráficos ilustrados, entre outros: a proliferação de periódicos no País sem tradição de casas editoras de livros; a emergência de tal entos literários eartistas plásticos que se valiam das revistas como espaço quase exclusivo para a colocação profissional; a modernização técnica da imprensa, otimizando as tiragens e os recursos gráficos. E mais uma coincidência, se lembrarmos aquela do texto parnasiano triunfante a competir com as molduras florais art-nouveau das páginas super - 
adjetivadas e exaustivamente decoradas que compunham as revistas ilustradas do período. ${ }^{7}$

As várias Revistas I lustradas, os tantos M agazines, trazendo os indefectíveis subtítulos - periódico ilustrado - atestavam a importância da imagem no circuito da imprensa, imagem cuja função não era mais a de complementar o texto, mas transformar a criação gráfica em texto. Assim como o Extra-texto, conforme denominação corrente para caracterizar, por exemplo, "a reclame" numa página impressa.

Por outro lado, para as novidades que o veículo colocava ao alcance de todos, a revista apresentava-se privilegiada em relação ao jornal. Fosse pela melhor resolução gráfica dos ultramodernos recursos visuais recém-apropriados, a exemplo da fotografia, linotipia, clichê em cores, etc., como por sua periodização mais espaçada, que permitia o tempo necessário para o trabalho mais detalhado da impressão, o que não se dava na imprensa diária.

Naquele impresso, os textos e as imagens - instrumentos da publicidade - reproduziram as transformações da virada do século, captadas através de recursos literários e gráficos, devolvidas ao público numa terceira dimensão, magnificando artigos, produtos, profissionais, estabelecimentos e serviços. N esse propósito, conjugaram-se literatura, arte e técnica, estreitando o convívio e descobrindo novas linguagens afins. $O$ desenho gráfico foi uma delas.

Logo, os experimentos técnicos al iados a novos recursos gráficos, a necessidade de transmitir a mensagem com rapidez - característica do periodismo em tempo de velocidade - e o hábil recurso de seduzir o público leitor, cativá-lo através da imagem, fizeram do ilustrador, fosse litógrafo, caricaturista, desenhista, pintor ou fotógrafo, o profissional imprescindível das revistas do período.

N este quadro de experimentos de toda ordem coube ao ilustrador - fosse ele pintor acadêmico, caricaturista ou artista gráfico - função de relevo no expediente das publicações. M ais que isso, ocupando o cargo de diretor artístico, muitas vezes acabou por definir linhas editoriais e pautas, dando praticamente o "tom" do periódico. Vale lembrar para o período em apreço nesta função o pintor Alfredo Norfini, 
na Revista M oderna, de São Paulo; J. Carlos, em O M alho, e Kalixto em Fon-Fon!, ambos no Rio de Janeiro.

A partir da obra do caricaturista Voltolino (1884-1926), por exemplo, Beluzzo inferiu a ilustração como instância definidora do programa do periódico, especialmente em se tratando de publicações menores, representativas de grupos de opinião. Circunscrita então ao ponto de vista editorial, compreendia "[...] a capa-abertura, destacando 0 evento mais significativo do corpo da revista; o desenho-comentário, da ocorrência polemizada no texto editorial; o desenho propiciando a entrada de mais de uma notícia; o desenho-cabeçal ho fixando as colunas da publicação."8

$\mathrm{N}$ a diversidade de ilustradores que emergem com o periodismo que se profissionaliza e ganha mercados, convém relacionar as respectivas especialidades de seus gêneros e traços, um dos muitos componentes significativos para a compreensão da imagem como documento. Numa ordem aproximada da colocação destes profissionais do traço, sucedem-se, com forte presença nas páginas revisteiras, o caricaturista, o ilustrador artístico, o artista da propaganda e o fotógrafo, responsáveis pelo acurado registro crítico de quem viveu edocumentou a época com talento e sensibilidade.

Vale uma aproximação maior neste universo de formas e cores.

Praticamente inaugural na ilustração periodística do Brasil, a caricatura comparece em A Lanterna M ágica, de M anuel Araújo Porto Alegre (1806-1879) e Rafael M endes de Carvalho, ainda em 1844, considerada uma das primeiras manifestações do gênero no País. Porto Alegre, romântico de primeira hora, vivenciara as experiências de Honoré Daumier (1808-1879) em Paris, e em típico processo de transplante das novidades de fora punha em circulação o cotidiano das mazelas e graças locais.

Naquelas circunstâncias, o gênero caricatura revelou-se ideal na comunicação do País de fraca população leitora, onde a imagem, e sobre- 
tudo o humor garantiam rápida absorção das mensagens, potencializando a comunicação periodística. Com mais alcance então que o texto e valendo-se de recursos de uma imprensa artesanal, estas primeiras imagens carregaram particular carga histórica, resultando hoje em matérias privilegiadas para inúmeras abordagens.

Em 1860, Henrique Fleuiss (1823-1882), em sua Semana I lustrada, estampava com forte tendência áulica - inevitável para o responsável pelo Imperial Instituto Artístico do Rio de Janeiro - a vida da Corte de nosso Império tropical. Não obstante, foi Angelo Agostini ((1843-1910), cronista implacável daquele cotidiano, quem estampou - entre luzes e sombras do esfumado de seu lápis litográfico - as aberrações de uma monarquia centralizadora, da sociedade de privilé gios, das vicissitudes do País escravocrata e clerical. Tudo está lá em sua Revista Ilustrada, que circulou por dezesseis anos: as campanhas da Abolição, da República, da laicização, a Guerra do Paraguai, crises ministeriais, os desencontros com a chegada anacrônica da modernidade técnica em terra de escravos, e tantas outras questões que pontuaram o Brasil Imperial.

0 gênero manteve-se em evidência até nossos dias, com humoristas gráficos talentosos que se apresentam nos periódicos, reproduzindo com espírito e argúcia parte dos bastidores e/ou do avesso da história; recurso que vem se revelando pertinente na sucessão de mídias e técnicas, atingindo agora aquela informatizada e televisiva.

0 avanço das técnicas de impressão, introduzindo a cor e ampliando as tiragens, criou espaço para a colocação do ilustrador gráfico no Brasil, artista que então realizou, com mais liberdade que na tradicional Academia de Belas Artes, experimentos de novas linguagens estéticas. Do inicial traço romântico, incorporou o art-nouveau, exercitou-se no art-déco, avançou pelo expressionismo e manifestações plásticas subseqüentes, encontrando na revista o suporte ideal para ensaios múltiplos, conformando-se-Ihe um primeiro campo profissio- 
nal. Emiliano Di Cavalcanti, que antes de ser artista do pincel foi artista do lápis, ilustra este processo. ${ }^{9}$ Todavia, esta instância em particular requer análise meticulosa, seja pela carga de informações que carrega, pela evolução significativa da forma e pelo aflorar de novas mentalidades que, subliminarmente, colocam-se neste circuito de representações. M anifestação que tem em E. H. Gombrich aportes teóricos oportunos, cuja abordagem da psicologia da representação pictórica constata que “(...) O bras de artenão são espelhos, mas, como espelhos, participam dessa ardilosa mágica de transformação, que é tão difícil definir em palavras." ${ }^{10}$

O conhecimento sobrea formação do artista esua rede de influências, patrocínios emercados evidencia-se como demanda premente para a análise desta nova produção artística, inserida em contexto diverso daquele tradicional e seleto dos raros cultores da arte. Em lugar da tela, apreciada por poucos, o papel impresso deflagrava a ampla divulgação da ilustração, dando na mesma proporção visibilidade inusitada ao artista.

I mporta reter que, no curso das transformações aceleradas que marcaram as revistas das décadas de 1890 a 1920, ressal tam os tempos defasados que coexistiram entre texto e imagem, revelando práticas e conteúdos em descompasso recíproco. Explica-se, em parte, o porquê. $\mathrm{N}$ a voragem de destruição do passado, perpetrada pela conexão intempestiva com a modernidade, surgiram grupos em defesa dos valores do País, temerosos da perda das raízes, calcados na herança romântica, imbuídos de nacionalismo, com forte presença nas revistas. Cultivando a tradição, buscando as origens, suas posturas iam do aprendizado do tupi-guarani ao endosso temático dos símbolos do "nacional", cantando com ênfase ufanista em prosa, verso e agora imagens, os valores da Pátria.

Concomitantemente, na esteira do arrebatamento pela vanguarda, vinha o envolvimento com novo repertório plástico que sintonizava a produção do campo artístico no Brasil - tida por conservadora - às vanguardas européias. Naquelas circunstâncias, a revista foi a embalagem industrial moderna para textos ainda de fatura parnasiana que, através de aparato gráfico avançado, expunha a discrepância en- 
tre o visual moderno e o interior antigo, ilustrando a defasagem cultural e a contradição de linguagens plásticas que passavam a expressar o País. No impresso, artistas do pincel também puderam exercitar-se por meio do desenho gráfico, e mais que isso, com liberdade de ensaio de novas formas de expressão, revelando a diversidade cultural do período.

Assiste-se, pois, através do periodismo, à veiculação exaustiva de símbolos, configuradores de grupos, classes sociais, partidos, governos, projetos, val endo-se da pluralidade de imagens e tratamentos gráficos. Desde o clichê de fatura francesa art-nouveau, ao verde-amarelo que pintou capas e páginas toscamente diagramadas com a cor da bandeira do Brasil, ou o preto e vermelho da bandeira paulista; da imagem que trocou o Zé Povo, do português Bordalo Pinheiro, pelo Jeca Tatu, de M onteiro Lobato, ou que se representou pelo exotismo oriental das pinturas da Academia, pelo evocativo mar de Benedito Calixto, a genuína roça de Almeida Júnior, as flores caipiras de nossos jardins das telas de Georgina de Albuquerque; ou ainda do traço ousado de Di Caval canti e aquele de Correa Dias. Afinal, em última instância, aquelas imagens também poderiam ser consumidas por um Brasil com $80 \%$ de sua população analfabeta.

N esse sentido, o periodismo paulistano reiterou práticas e conteúdos em descompasso recíproco. No tocante às técnicas de impressão, imperaram recursos de vanguarda, enquanto os conteúdos veiculados guardavam laivos, senão cultivo explícito da tradição.

FAÇA PUBLICIDADE OU SE ARREBENTE!

Todavia, invadindo as páginas revisteiras com vigor, das contracapas às quartas capas finais - na maioria das vezes fundamento da própria existência do periódico - vinha incisivo o desenho publicitário. E dos vários suportes que se prestaram à propaganda eà publicidade, a revista talvez tenha sido dos mais efetivos, concentrando a força da propaganda ea evolução dinâmica da publicidade, expressando-as em suas representações mais acabadas. ${ }^{11}$

Para a publicidade, em particular, tornou-se de tal forma o veícu- 
lo ideal que, em sua essência, quase se confundia com ela, uma vez que ambas, revista e publicidade, direcionavam-se para o mesmo propósito, qual seja: dar-se a conhecer, divulgar-se, "produzir-se para venderse". Razão pela qual muitos periódicos revelaram-se economicamente viáveis tão-só pela proposta de divulgação de produtos, isto é, pelo seu caráter publicitário. A revista, pois, era a publicidade; ou por outra, no periodismo da época, a revista transformou-se na embalagem certa do produto publicidade.

E os trânsitos do artista gráfico se repetiram quando inferiu naquele segmento, um novo campo profissional. Caricaturistas e pintores da Academia valeram-se da demanda publicitária, colocando-se a serviço de conglomerados industriais que se estabeleciam no Brasil. Voltolino foi responsável pela veiculação do Guaraná Espumante Zanotta, e Humberto Della Latta - Iaureado pintor que estagiara na I tália - mostrava seu traço no mercado a serviço dos Chocolates Lacta e Falchi. De outro teor publicitário, também o cartaz de anúncio da Semana de 22, desenhado por Di Caval canti, insere-se nesse quadro de experimentos diversificados, que a propaganda e a publicidade puseram em circulação e que tiveram nas revistas o instrumento ideal para sua propagação.

\section{MÁGICO EFEITO MULTIPLICADOR}

Contudo, coube à fotografia invadir decisivamente aquel e periodismo como recurso de ilustração, concorrendo com artistas do lápis, da tinta e do pincel. Sua utilização revelou-se de extrema utilidade, fosse para definir as capas com personagens, paisagens, vistas urbanas, ou a serviço da reportagem fotográfica, documentando a transformação da cidade, as cerimônias de impacto nos âmbitos político e social, as reportagens sensacionalistas, festas e eventos de toda ordem. ${ }^{12}$

A categoria fotográfica, até então indefinida, assumiu foros profissionais, encontrando no periodismo o espaço adequado de colocação. Não só para reproduzir a personalidade do momento na capa das revistas de sucesso, mas para flagrar os instantâneos urbanos que ex- 
punham novos hábitos e sociabilidades em meio a tantas transformações, veiculando a modernidade que se procurava imprimir nos espaços da cidade. Contratados por grandes companhias, sobretudo estrangeiras, e pelos governos republicanos que descobriam a propaganda e publicidade profissionais, cuidavam de reproduzir imagens de acordo com as encomendas, focando e imprimindo tão-somente o idealizado.

É sabido o compromisso destes profissionais com a solicitação dos clientes no propósito de matizar a realidade, amoldando-a a seus interesses e aspirações. Vem neste sentido - com toda a qualidade técnica - a produção do fotógrafo Guilherme Gaensly (1843-1928), que reproduziu cenas idílicas da vida no campo e imagens urbanas de fatura superior com vistas a, respectivamente, estimular a imigração e divulgar a qualidade e sociabilidade da cidade, ou melhor, sua "civilidade". ${ }^{13}$ I magens que estampadas no periódico da moda garantiam seu consumo, e quando divulgadas lá fora, creditavam o País à aprovação do investidor estrangeiro.

Insista-se, por fim, que o poder multiplicador da fotografia transformou-a em recurso ideal naquela imprensa de público tão particular, vale dizer: dependente das dimensões continentais do País, ainda servido de fracos meios de distribuição; de reduzida população alfabetizada e mais ainda de população efetivamente leitora; de poder aquisitivo incipiente, e inclusive, desconhecendo a tradição de leitura, só agora encetada e facilitada pela efervescência do periódico, um de seus mais exemplares propagadores.

Ao final desse texto, as sedutoras revistas ilustradas, descamadas, talvez se apresentem como documentos temerários, demandando amplo cabedal teórico para sua análise, bem como rigor crítico exacerbado. Longe de permitir viagens pelo tempo pretérito, embaladas apenas nas emoções pictóricas e textuais daquelas páginas repletas de magia, seu manejo requer do historiador o domínio de vários campos de conhecimento, quanto mais variadas forem as dimensões daqueles impressos e, sobretudo, se atrelados ao aposto "DeVariedades".

Forma e conteúdo, em ritmos diferenciados, conferiram traços peculiares àquele periodismo que preparou a grande imprensa, avançado quanto ao tratamento gráfico eainda retrógrado em sua propos- 
ta editorial. As máquinas modernas podiam ser adquiridas com o dinheiro fácil do café e da indústria nascente, enquanto o domínio da técnica era apenas uma questão de dedicação a seu aprendizado. Quanto aos textos, à veiculação de conteúdos, atrelavam-se a um quadro mental referenciado pelo caráter do País, de tradição escravocrata, marcado pelo domínio da religião católica, mas que se mostrava ávido em exibir ao mundo a representação de seu recente e voraz progresso. Dai o forte apelo das mensagens presididas pela ilustração e, mais que isso, pelos símbolos do progresso que aquela imprensa tão diversificada cuidou de veicular, poderosamente instrumentalizada pelos recursos gráficos do mercado.

Naquela produção, a imagem resultou, por vezes, mais eficaz que a letra. A fotografia - com seu poder multiplicador - potencializou a informação, levando aos mais diversos públicos a informação atéentão subtraída ao analfabeto e às camadas desfavorecidas. Sua mensagem atingia indistintamente 0 letrado, 0 semi-alfabetizado e atéo analfabeto. 0 alcance foi imenso, levando-se em conta a força da imagem, sempre procedente no conjunto, da esfera do simbólico. ${ }^{14}$

Logo, o periodismo daquela virada de século - qualificado por clichês de elaboração filigranática, litografias precisas, imagens arrebatadoras de rotogravura, caricaturas inventivas, ilustrações florais artnouveau, crônicas parnasianas e soluções fotográficas inusitadas - resulta em acervo rico, porém arriscado. Mais ainda, a serviço da publicidade, em que o recurso "da reclame" passa a ser a dimensão inovadora da propaganda.

Razão pela qual o mergulho real nas tantas vertentes propiciadas pelas revistas requer estratégias de análise. Relativizar os registros decorrentes das aliciantes imagens de superfície matizadoras de mensagens, mascaradas pelos recursos técnicos e pelo texto da propaganda, constitui-se em aporte para a competente incursão neste documento múltiplo. Assim como o confronto com aspectos aparentemente menores de sua fatura e circulação - seja aquele do papel utilizado ou da diagramação adotada, seja aquele outro da forma de distribuição e locais de venda. Cada uma destas circunstâncias merece considerações que, finalmente, agregam-Ihe, de fato, 0 imenso potencial de fonte his- 
tórica. Através destes percursos, é possível aproximar-se com mais riqueza do contraponto do conteúdo destilado, do reverso da medal ha e, de forma cabal, do ethos cultural de toda uma época.

M ARTINS, A.L. From fantasy to History: Unfolding sources inside magazines. História. São Paulo, v.22, n. 1, pp. 59 a 79, 2003.

\begin{abstract}
A B S T RACT: This article deals with the use of magazines as sources of History, trying to point out its characteristics as a multiple document serving to recover history, also stressing the need of a preliminary, exhaustive critical evaluation, due to the mercantile and/or ideological nature of these publications. Concomitantly, the paper reveals two aspects that deserve an accurate study involving the magazines: the target reading population, which defines its editorial line, and the illustrations, important part of its core, not forgetting to mention the specific sections that complete the publications. The examples studied are magazines issued in São Paulo City, within the period 1890/1920.
\end{abstract}

KEY wo R D s: magazine, illustration, São Paulo City History

\title{
NOTAS
}

${ }^{1}$ Historiadora do Condephaat - Secretaria de Estado da Cultura - CEP 01028900 - São Paulo - SP.

${ }^{2}$ Iris: Revista M ensal de Letras, Ciências eArtes. São Paulo: Tip. Andrade \& M ello, ano I, n.1, pp.16-17, nov. 1905.

${ }^{3}$ Ver M ARTINS, A. L. Revistas em revista. Imprensa e práticas culturais em tempos de República. São Paulo, 1890-1922. São Paulo: EDUSP: FAPESP, 2001.

${ }^{4}$ M ARSO N, M . I. Da Feminina "macha" aos Homens Sensíveis. Cadernos AEL, UNICAM P, Campinas, ns. 3-4, 1995-1996.

${ }^{5}$ DUARTE, P. História da Implantação da Imprensa no Brasil: Imprensa de São PauIo. São Paulo: ECA-USP, 1972, pp. 72 e 25.

${ }^{6}$ PRAD O, A. A. (org). Libertários no Brasil. M emórias, Lutas, Cultura. São Paulo: Brasiliense, 1986; H ARDM AN, F. F. N em Pátria, nem Patrão! Vida operária e cultura anarquista no Brasil. São Paulo: Brasiliense, 1983. 
${ }^{7}$ SU SSEKIND, F. Cinematógrafo das Letras: Literatura, Técnica e M odernização no Brasil. São Paulo: Companhia das Letras, 1987, pp. 36- 37.

${ }^{8}$ BELLLUZO, A. M . de M. Voltolino e as raízes do modernismo. (D outorado em Comunicações e Artes). ECA, USP, São Paulo, s/d., p. 34 (grifo nosso).

${ }^{9}$ SIMIONE, A. P. Di Cavalcanti, ilustrador. São Paulo: Sumaré: FAPESP, 2002.

${ }^{10} \mathrm{GOM}$ BRICH , E. H . Arte ellusão. Um estudo da psicologia da representação pictórica. São Paulo: M artins Fontes, 1986, p. 5.

${ }^{11}$ Ver: OBERLAEN DER, R. Publicidadee Propaganda. Rio de Janeiro: Shogun Arte, 1984; M ALAN GA, E. Publicidade, uma introdução. São Paulo: Atlas, 1976, p.11; GUZM AN , J. R. S. Breve Historia de la Publicidade. M adrid: Ediciones Forja S.A., 1982; RAM OS, R. D o reclame à comunicação: pequena história da propaganda no Brasil. São Paulo: Atual Editora, 1985.

${ }^{12}$ CAM ARGO, M. J. de; M EN DES, R. Fotografia. Cultura e Fotografia Paulistana no século XX. São Paulo: SM C, 1992, pp. 16 a 41, especialmente.

${ }^{13}$ KOSSOY, B. São Paulo 1900. São Paulo: CBPO, 1990.

${ }^{14}$ AU M O NT, J. A Imagem. Campinas: Papirus, 1993, p. 81.

Artigo recebido em 04/2003. A provado em 05/2003. 